\title{
Pengaruh Panjang Kolom Distilasi Bahan Isian Terhadap Hasil Produk Cair Sampah Plastik
}

\author{
Isti Nur Azizah ${ }^{1}$, Ninda Puspita Sari ${ }^{1}$, Maryudi ${ }^{1}{ }^{1, *}$ \\ ${ }^{1}$ Program Studi Teknik Kimia, Universitas Ahmad Dahlan, Jln. Prof. Dr. Supomo, SH., Warungboto, \\ Yogyakarta 55164 \\ *email: maryudi@che.uad.ac.id
}

\begin{abstract}
Plastic waste is a problem that has to be taken seriously for the pollution of the environment, especially for land contamination. For now, the handling of plastic waste normally disposed (landfills), burned or recycled (recycle). At burning of plastic waste is usually carried out by pyrolysis method to produce plastic oil. To get the maximum results needed further analysis in the form of purification by distillation, where the distillation is a method that can be used for advanced analysis, one with a distillation column. Fractional distillation is often called the distillation column is to separate liquid components, two or more, of a solution based on differences in their boiling points. This distillation can also be used to mix with boiling point less than $20^{\circ} \mathrm{C}$ and work at atmospheric pressure or low pressure. Application of this type is used in the distillation of crude oil industry, to separate the components in the crude oil distillation Differences simple fractionation and distillation is the fractionation column. In this column warming occurs gradually with different temperatures on each license plate. Different heating is intended for refining distillates from the plates underneath. Getting to the top, the less volatile liquid. The distillation process depends on the characteristics of the vapor pressure of a liquid mixture of components.

The distillate was obtained at temperature of $195^{\circ} \mathrm{C}, 200^{\circ} \mathrm{C}, 220^{\circ} \mathrm{C}, 235^{\circ} \mathrm{C}$ and $240^{\circ} \mathrm{C}$ and the most products component of pyrolysis plastic in previous research was obtain at $195^{\circ} \mathrm{C}, 200^{\circ} \mathrm{C}$ and $220^{\circ} \mathrm{C}$
\end{abstract}

Keywords: Distillation, Liquid Waste Plastic Products, Carbon

\section{Pendahuluan}

Sampah plastik merupakan masalah yang sudah dianggap serius bagi pencemaran lingkungan khususnya bagi pencemaran tanah. Untuk saat ini, penanganan limbah plastik umumnya hanya dibuang (landfill), dibakar atau didaur ulang (recycle). Di Indonesia, kebutuhan kemasan yang terus meningkat dari kalangan industri membuat industri plastik terus bertumbuh. Bahan baku plastik yang biasa dibutuhkan pasar, adalah polietilena (PE) dan polipropilena (PP). Untuk konsumsi plastik jenis PE, tahun lalu mencapai 800.000 ton. Adapun konsumsi plastik PP mencapai sebesar 900.000 ton [1].

Beberapa penelitian seputar konversi sampah plastik menjadi produk cair berkualitas bahan bakar telah dilakukan dan menunjukkan hasil yang cukup prospektif untuk dikembangkan Salah satu metode yang dapat digunakan dengan metode pirolisis untuk mengkonversi limbah plastik menjadi minyak, sedangkan pirolisis atau devolatilisasi adalah proses fraksinasi material oleh suhu [2].

Untuk mendapatkan hasil yang lebih maksimal diperlukan analisis lanjutan berupa pemurnian dengan destilasi, dimana destilasi merupakan metode yang dapat digunakan untuk analisis lanjutan, salah satunya dengan destilasi kolom. Destilasi kolom merupakan proses pemisahan secara diffuse berdasarkan volatilitas dari komponen-komponen yang ada akibat perbedaan titik didih masing-masing komponen. Proses distilasi tergantung kepada karakteristik tekanan uap suatu komponen campuran cairan [3].

Produk cair sampah plastik yang akan didestilasi yaitu bahan bakar minyak jenis distilat berwarna coklat kehitaman. Warna coklat kehitaman tersebut akibat adanya pembakaran pada suhu dekomposisi $450^{\circ} \mathrm{C}$ serta zat pewarna organik yang terkandung dalam sampah plastik [4].

Distilasi fraksionasi adalah memisahkan komponen-komponen cair, dua atau lebih, dari suatu larutan berdasarkan perbedaan titik didihnya. Distilasi ini juga dapat digunakan untuk campuran dengan perbedaan titik didih kurang dari $20^{\circ} \mathrm{C}$ dan bekerja pada tekanan atmosfer atau dengan tekanan rendah. Aplikasi dari distilasi jenis ini digunakan pada industri minyak mentah, untuk memisahkan komponen-komponen dalam minyak mentah Perbedaan distilasi fraksionasi dan distilasi sederhana adalah adanya kolom fraksionasi. Di kolom ini terjadi pemanasan secara bertahap dengan suhu yang berbeda-beda pada setiap platnya. Pemanasan 
ISSN: $2355-875 X$

yang berbeda-beda ini bertujuan untuk pemurnian distilat yang lebih dari plat-plat di bawahnya. Semakin ke atas, semakin tidak volatil cairannya [5].

Pemanfaatan limbah plastik menjadi produk cair telah banyak dilakukan, namun biasanya proses yang dilakukan hanya sebatas pembakaran pada proses pirolisis saja yang telah menghasilkan biofuel. Namun, kenyataannya, proses pemakaian biofuel secara nyata masih memerlukan jangka waktu yang lama untuk sampai dihasilkan produk siap pakai [6].

\section{Metode Penelitian}

Bahan: bahan utama penelitian yang digunakan adalah produk cair sampah plastik (PCSP) yaitu hasil pirolisis sampah plastik pada suhu $450^{\circ} \mathrm{C}$ berwarna coklat kehitaman, sampah plastik yang dipirolisis merupakan campuran berbagai jenis plastik dan produk cair hasil, dimana warna coklat kehitaman pada produk cair sampah plastik (PCSP) akibat adanya pembakaran pada suhu dekomposisi $450{ }^{\circ} \mathrm{C}$ serta zat pewarna organik yang terkandung dalam sampah plastik. Serta air kran untuk proses pendinginan dalam kondensor.

Alat: distilasi produk cair sampah plastik (PCSP) hasil pirolisis pada percobaan pendahuluan meggunakan serangkaian alat distilasi kolom berisolasi dengan 3 panjang kolom yang bervariasi yaitu $40 \mathrm{~cm}$, $60 \mathrm{~cm}, 80 \mathrm{~cm}$. Dimana alat utamanya yaitu kolom distilasi yang berisi packing untuk memaksimalkan terpisahnya fraksi ringan dan fraksi berat. serta dilengkapi dengan isolasi yang berfungsi untuk menjaga kestabilan suhu dan meminimalkan adanya transfer panas pada kolom, kolom dilengkapi dengan pemanas listrik sebagai pemanas, kondensor menurunkan temperatur gas cair selama pemanasan yang dihasilkan dari proses disilasi, pengukur suhu (thermometer) untuk mengetahui suhu tetesan dan suhu didih sampel, dan pengukur tekanan sebagai pengatur suhu untuk menjaga kestabilan suhu. Untuk proses pemisahan produk cair sampah plastik dapat dilihat pada gambar 1 .

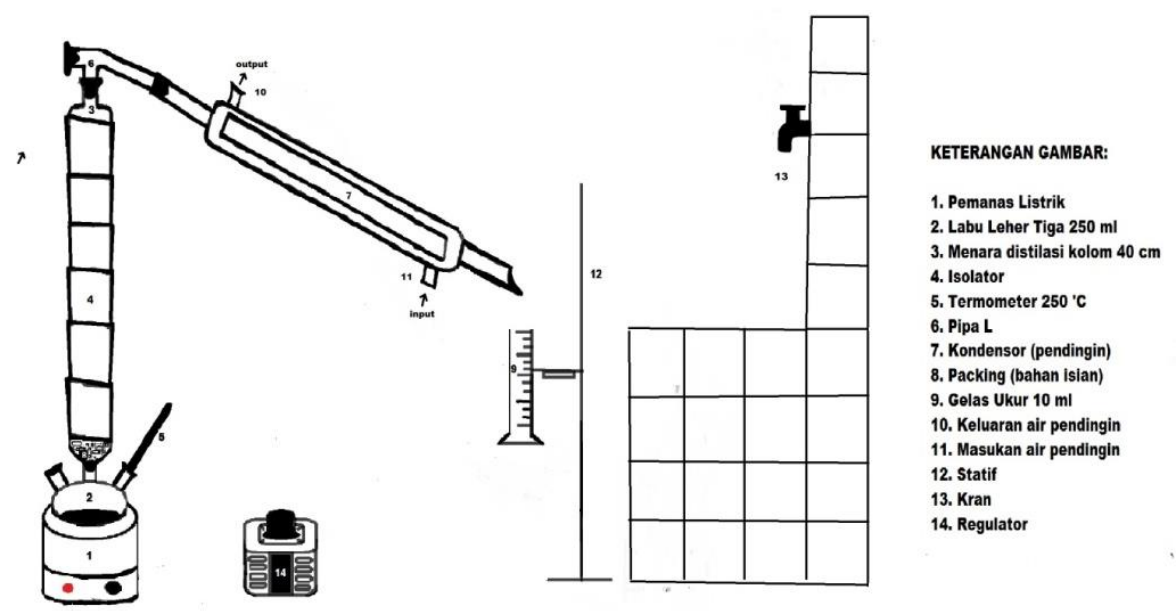

Gambar 1. Rangkaian Alat Penelitian

Prosedur Penelitian: Prosedur secara umum dapat dilihat pada Gambar 2. Dimana 200 ml produk cair sampah plastik dipanaskan hingga mendidih dalam labu leher tiga, setelah mendidih, catat suhu didih PCSP sebagai data dan menunggu hingga terjadi tetesan, saat terjadi tetesan catat suhu awal terjadi tetesan, dan mengukur volum distilat tiap interval 5 menit hingga menit ke 30. Lakukan langkah yang sama untuk tetesan yang terjadi setiap kenaikan suhu .Selama proses pemanasan berlangsung, air pendingin dalam kondensor harus selalu dialirkan untuk menghindari adanya superheated yang dapat menyebabkan ledakan. Selama terjadi tetesan kestabilan suhu harus dijaga dengan regulator untuk mendapatkan keakuratan hasil distilat. Setelah kenaikan suhu mencapai maksimal suhu pada termometer, proses dapat dihentikan. Kemudian mengukur dan mencatat volum residu yang dihasilkan dalam labu lehe tiga. Hasil distilat tiap tetesan kemudian dianalisis dengan uji GCMS untuk mengetahui kandungan apa saja yang terkandung dan berapa prosentasenya. 


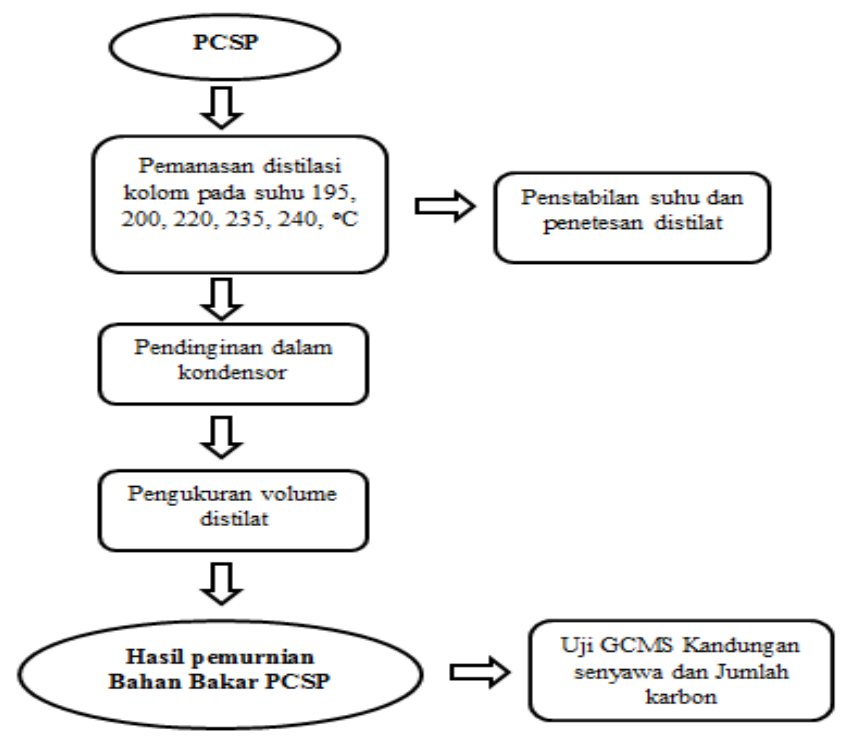

Gambar 2. Prosedur penelitian

\section{Hasil dan Pembahasan}

\section{Kandungan Senyawa PCSP}

Dari penelitian diperoleh destilat produk cair sampah plastik pada temperatur $195^{\circ} \mathrm{C}, 200^{\circ} \mathrm{C}, 220^{\circ} \mathrm{C}, 235^{\circ} \mathrm{C}$ dan $240^{\circ} \mathrm{C}$ sebanyak masing masing dengan total volume $2,6 \mathrm{~mL}, 1,6 \mathrm{~mL}, 1,3 \mathrm{~mL}, 0,4 \mathrm{~mL}$, dan $2,6 \mathrm{~mL}$. Berikut adalah grafik jumlah volume dalam satuan waktu pada setiap temperatur.

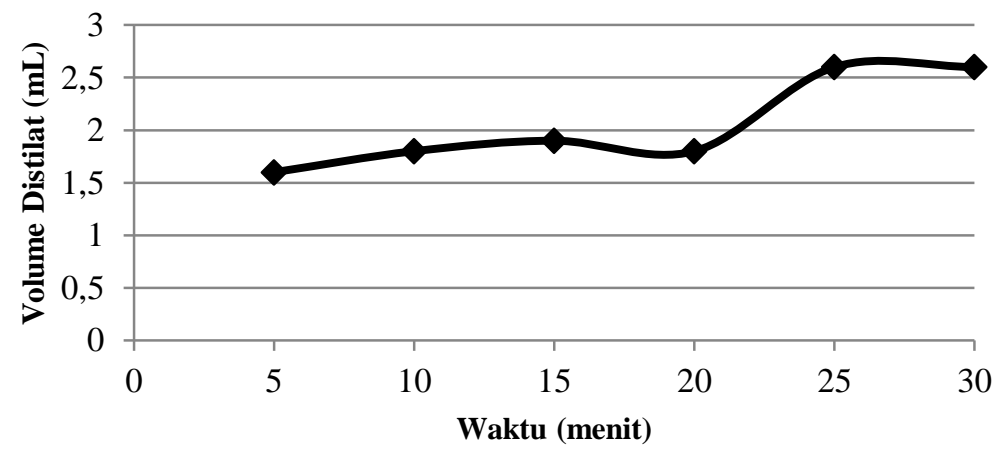

Gambar 3. Grafik hubungan volume distilat terhadap waktu pada temperatur $195^{\circ} \mathrm{C}$

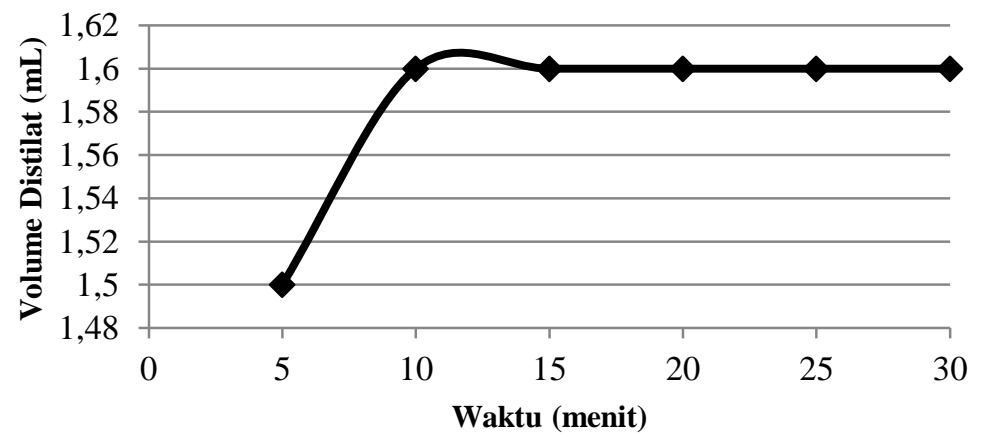

Gambar 4. Grafik hubungan volume distilat terhadap waktu pada temperatur $200^{\circ} \mathrm{C}$ 


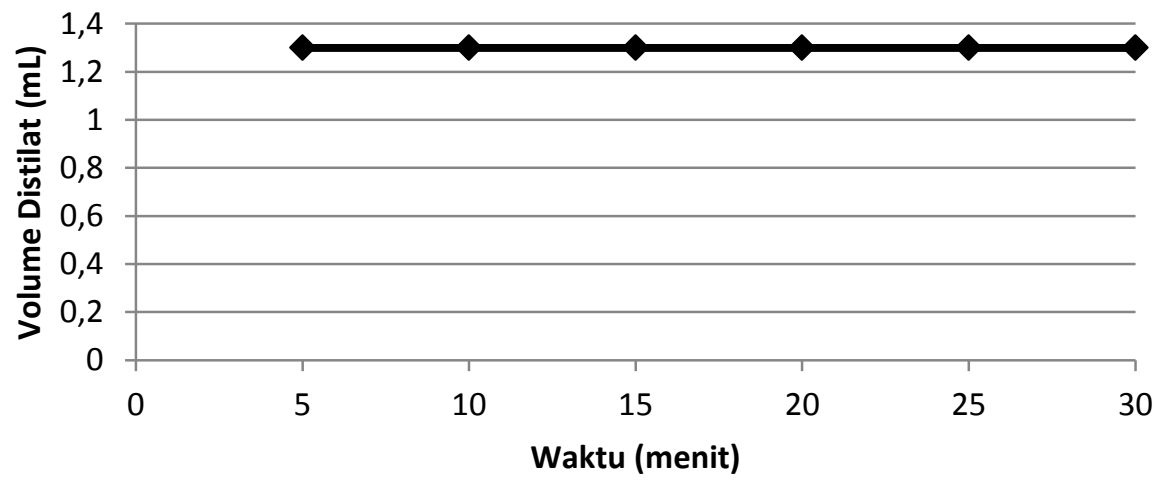

Gambar 5. Grafik hubungan volume distilat terhadap waktu pada temperatur $220^{\circ} \mathrm{C}$

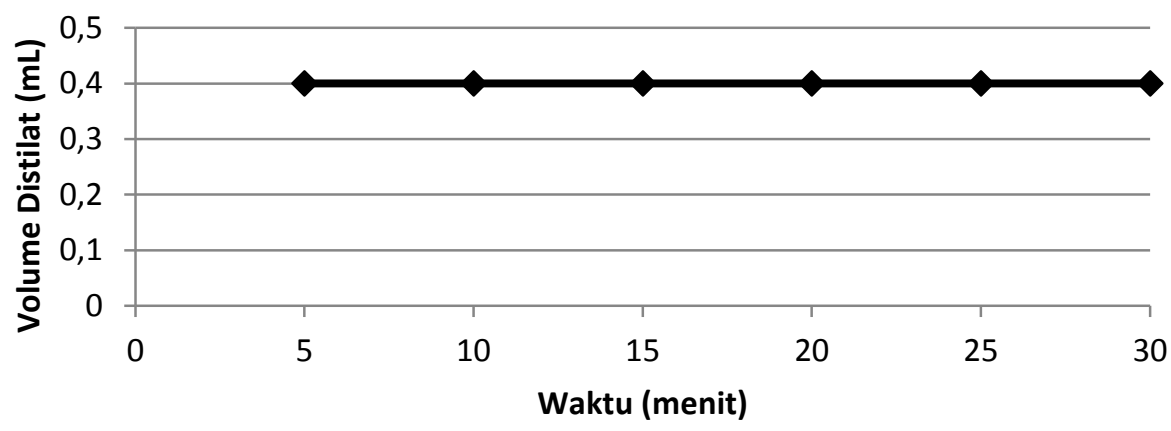

Gambar 6. Grafik hubungan volume distilat terhadap waktu pada temperatur $235^{\circ} \mathrm{C}$

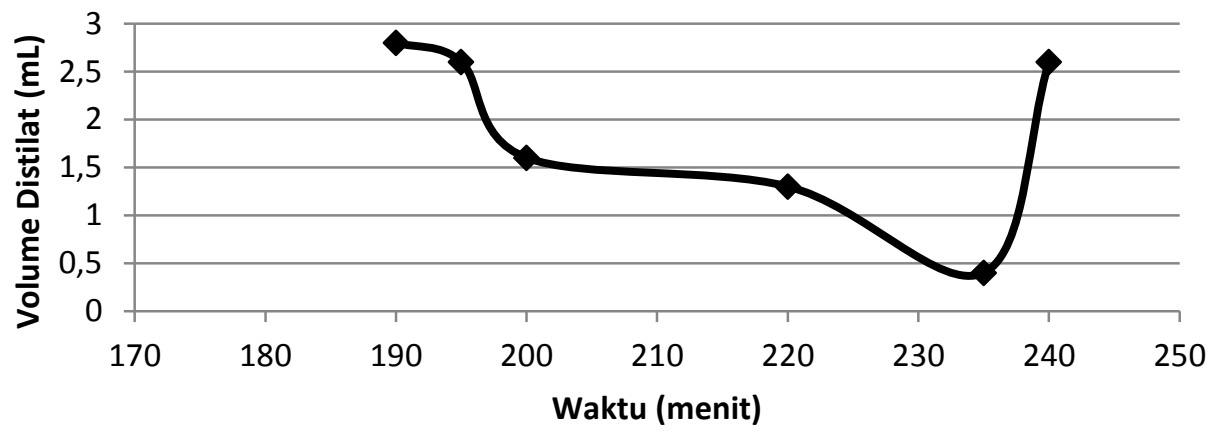

Gambar 7. Grafik hubungan volume distilat terhadap temperatur distilasi

Dari grafik diatas dapat disimpulkan bahwa fraksi terbanyak dari pirolisis plastik campuran terseleksi pada temperatur $450^{\circ} \mathrm{C}$ adalah komponen hidrokarbon yang memiliki titik didih $195^{\circ} \mathrm{C}, 200^{\circ} \mathrm{C}$ dan $200^{\circ} \mathrm{C}$.

Hasil distilasi kemudian di uji dengan uji GCMS di Laboratorium Farmasi Universitas Ahmad Dahlan Yogyakarta pengujian ini dilakukan untuk mengetahui kandungan senyawa dan jumlah unsur hidrokarbonnya. Hasil uji GCMS terlihat bahwa sampel PCSP mengandung banyak senyawa, hal ini bisa diketahui dari banyaknya puncak (peaks) dalam spectra GC tersebut. Setiap peaks mengambarkan senyawa kimia yang terkandung dalam sampel. Hasil penelitian menunjukan bahwa sampel PCSP akan menghasilkan kecenderungan pembentukan unsur hidrokarbon yang bervariasi dari proses pirolisis. Pengujian chromatogram destilat PCSP pada suhu $200^{\circ} \mathrm{C}$ terdapat 25 peaks sedangkan suhu $220^{\circ} \mathrm{C}$ terdapat 50 peaks yang tercatat pada gambar 3 dan 4 . 


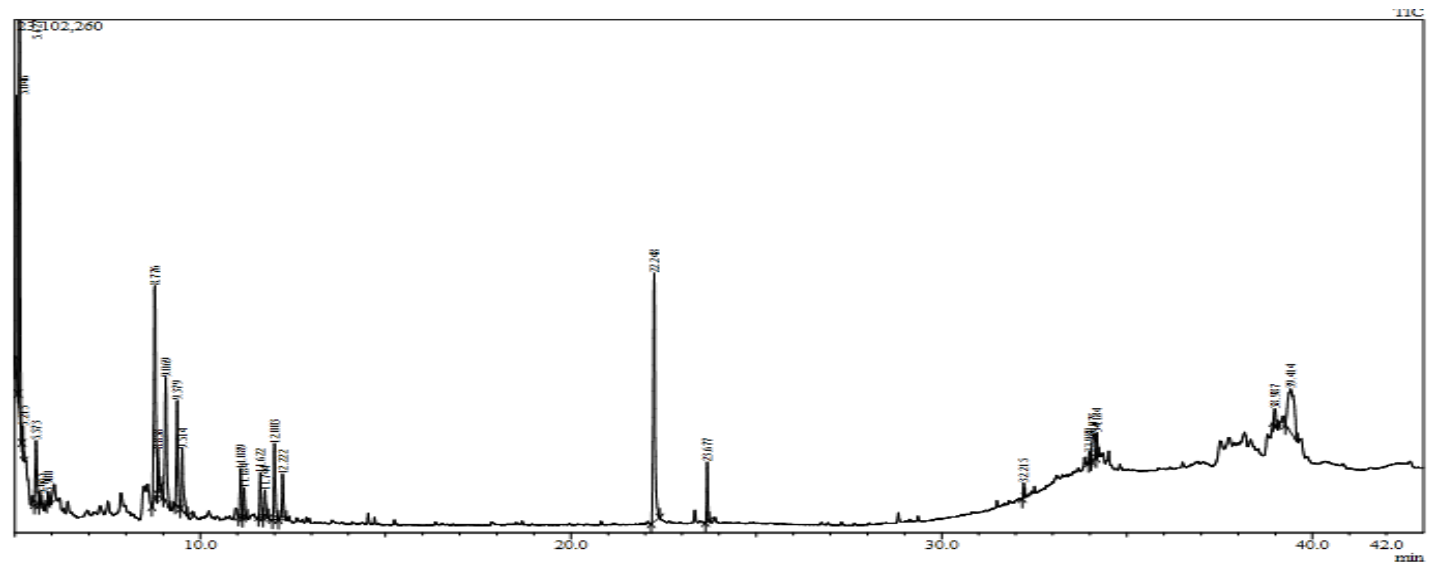

Gambar 8. Hasil Uji GCMS pada Temperature $200{ }^{\circ} \mathrm{C}$

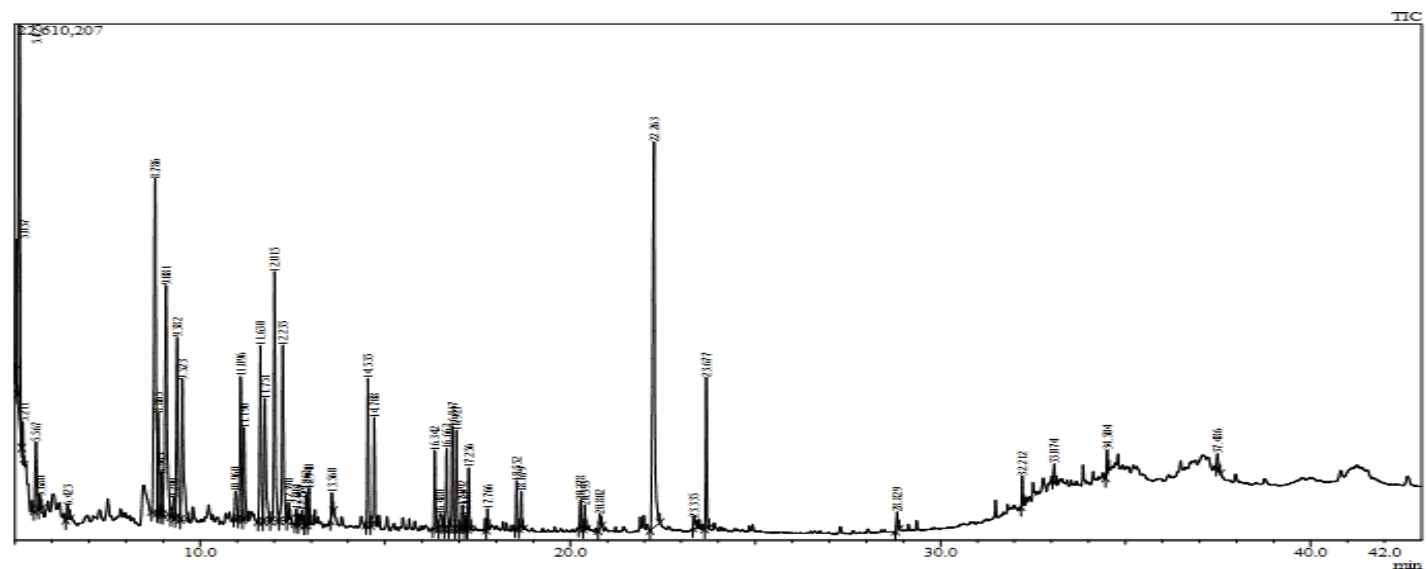

Gambar 9. Hasil Uji GCMS pada Temperature $220{ }^{\circ} \mathrm{C}$

Dari keseluruhan jumlah peaks dalam masing-masing suhu kemudian didapatkan presentase area tertinggi dengan kandungan senyawa terlihat pada tabel 1.

Tabel 1. Data GC pada Temperature $200{ }^{\circ} \mathrm{C}$

\begin{tabular}{|c|c|c|l|c|c|}
\hline No & Peak & $\%$ Area & \multicolumn{1}{|c|}{ Senyawa Kimia } & Formula & Jenis \\
\hline 1 & 2 & 16.25 & Nonane (CAS) n-Nonane & $\mathrm{CH}(\mathrm{CH}) 7 \mathrm{CH} 3$ & alkana \\
\hline 2 & 1 & 13.19 & Styrene & $\mathrm{C}_{8} \mathrm{H}_{8}$ & Polimer \\
\hline 3 & 18 & 12.38 & 1,2 -Benzenedicarboxylic acid, diethyl ester (CAS) Ethyl phthalate & $\mathrm{C} 12 \mathrm{H} 14 \mathrm{O} 4$ & lain-lain \\
\hline 4 & 7 & 11.21 & 1-Decene (CAS) Dec-1-ene & $\mathrm{C} 10 \mathrm{H} 20$ & rantai panjang \\
\hline 5 & 25 & 7.37 & Tetradecanoic acid, phenylmethyl ester & $\mathrm{C} 21 \mathrm{H} 34 \mathrm{O} 2$ & rantai panjang \\
\hline
\end{tabular}

Tabel 1 menunjukan lima unsur kimia dengan prosentase tertinggi. Prosentase tertinggi pertama adalah Nonane $\left(\mathrm{CH}_{3}\left(\mathrm{CH}_{2}\right)_{7} \mathrm{CH}_{3}\right)$ sebesar 16,25\% diikuti oleh Styrene $\left(\mathrm{C}_{8} \mathrm{H}_{8}\right)$ 13,19\%, Benzene $\left(\mathrm{C}_{12} \mathrm{H}_{14} \mathrm{O}_{4}\right)$ 12,38 \%, 1-Decane $\left(\mathrm{C}_{10} \mathrm{H}_{20}\right)$ 11,21\% dan Tetradecanoic $\left(\mathrm{C}_{21} \mathrm{H}_{34} \mathrm{O}_{2}\right) 7,37 \%$.

Tabel 2. Data GC pada Temperature $220{ }^{\circ} \mathrm{C}$

\begin{tabular}{|c|c|c|c|c|c|}
\hline NO & PEAKS & $\%$ AREA & SENYAWA & FORMULA & JENIS KLASIFIKASI \\
\hline 1 & 43 & 10.83 & 1,2-Benzenedicarboxylic acid, diethyl ester (CAS) Ethyl phthalate & C12H14O4 & rantai panjang \\
\hline 2 & 7 & 9.52 & 1-Decane (CAS) & C10H20 & Alkana \\
\hline 3 & 2 & 8.49 & Nonane (CAS) n-Nonane & CH3(CH2)7CH3 & Alkana \\
\hline 4 & 10 & 6.88 & Decane (CAS) & C10H20 & Alkana \\
\hline 5 & 19 & 5.49 & Cyclopropane, nonyl- (CAS) & C3H6 & siklo alkana \\
\hline
\end{tabular}

Tabel 2 menunjukan lima unsur kimia dengan prosentase tertinggi. Prosentase tertinggi pertama adalah Benzene $\left(\mathrm{C}_{12} \mathrm{H}_{14} \mathrm{O}_{4}\right)$ sebesar 10,83\% diikuti oleh 1-Decane $\left(\mathrm{C}_{10} \mathrm{H}_{20}\right)$ 9,52\%, Nonane $\left(\mathrm{CH}_{3}\left(\mathrm{CH}_{2}\right)_{7} \mathrm{CH}_{3}\right) 8,49$ $\%$, Decane $\left(\mathrm{C}_{10} \mathrm{H}_{20}\right) 6,88 \%$ dan Cyclopropane $\left(\mathrm{C}_{3} \mathrm{H}_{6}\right) 1,64 \%$. 

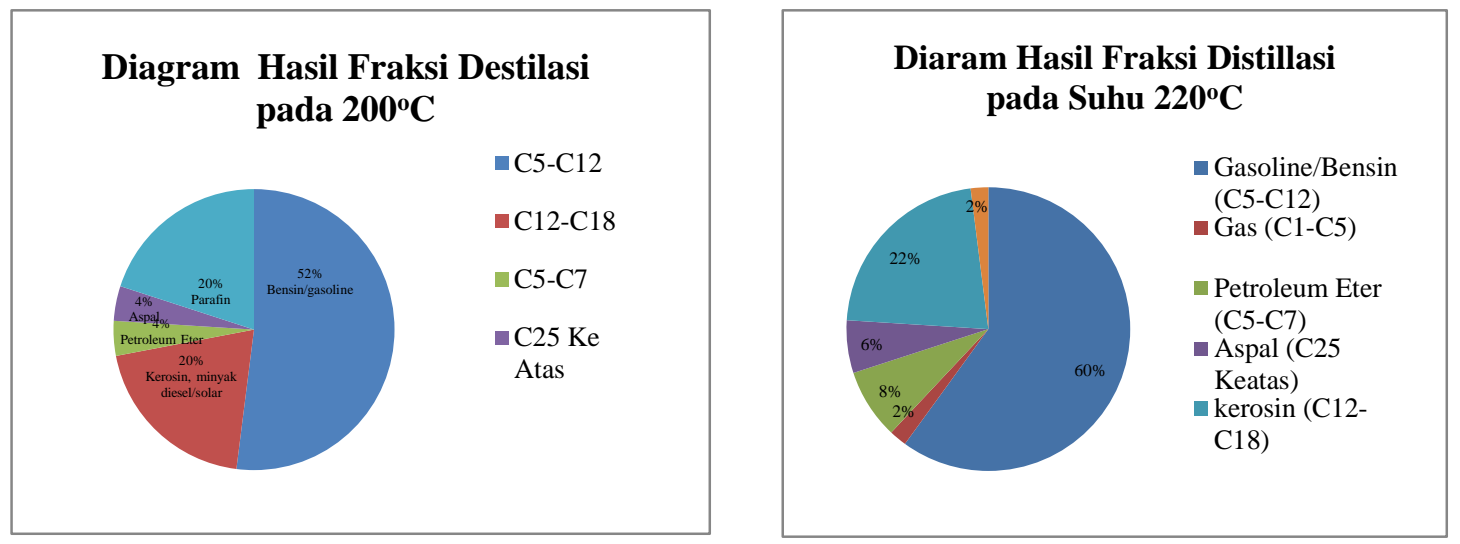

Gambar 10. Diagram hasil fraksi distilasi pada $200^{\circ} \mathrm{C}$ dan $220^{\circ} \mathrm{C}$

Dilihat dari kandungan senyawa hidrokarbon, selain penentuan terhadap distribusi rantai karbon, pengamatan terhadap klasifikasi senyawa hidrokarbon juga telah dilakukan, seperti Diagram fraksi diatas. Penentuan senyawa hidrokarbon ditentukan oleh formula dasar dari setiap senyawa hidrokarbon seperti Paraffin $(\mathrm{CnH} 2 \mathrm{n}+2)$, Olefin $(\mathrm{CnH} 2 \mathrm{n})$, Napthane $($ Cyclo $\mathrm{CnH} 2 \mathrm{n})$, Aromatik $(\mathrm{CnH} 2 \mathrm{n}-6$ dan $\mathrm{CnHn})$ dan Acetylene ( $\mathrm{CnH} 2 \mathrm{n}-2)$ [7], senyawa selain dari kelima formula senyawa hidrokarbon tersebut dimasukkan di dalam kelompok senyawa others. Formula dan nama senyawa kimia dari Produk Cair Sampah plastik diketahui dari hasil uji GCMS. Hasil pengamatan menunjukkan bahwa hasil komposisi bahan baku Produk Cair Sampah plastik pada proses distillasi menentukan arah kecenderungan pembentukan senyawa-senyawa hidrokarbon yang dihasilkan. Fungsi paraffin sendiri adalah sebagai pelumas pada mesin. Fungsi aromatik sebagai anti knocking yang tinggi dan sabilitas penyimpanan yang baik [4,5]. senyawa paraffin biasanya cenderung memiliki massa jenis bahan bakar yang rendah namun memiliki nilai kalori yang lebih besar relatif dibanding dengan bahan bakar dari senyawa nepthane [7].

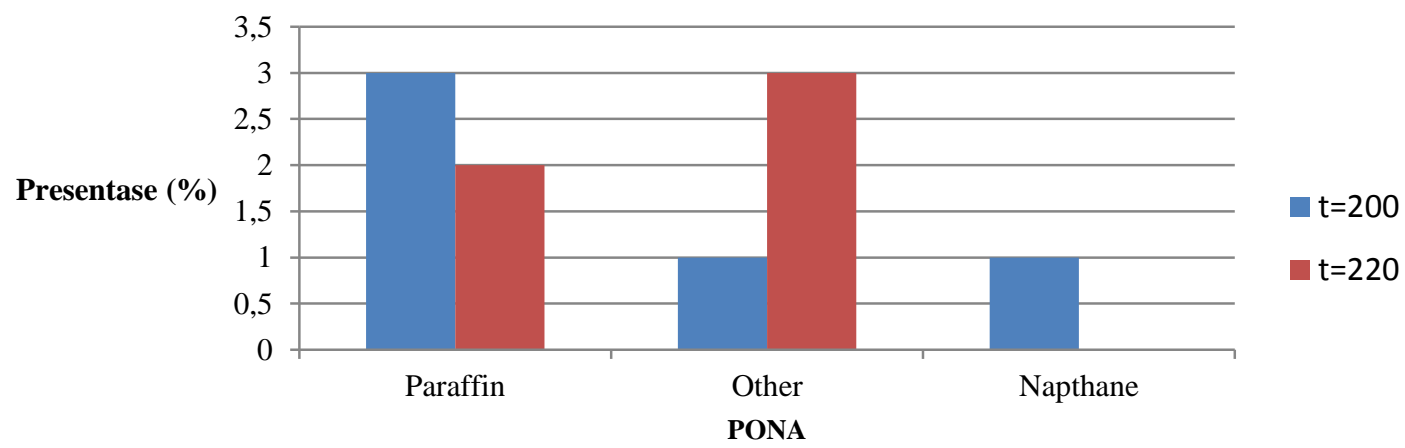

Gambar 11. Grafik distribusi PONA (Parrafin, Olefin, Naphtane, Aromatic dan Acetylene)

\section{Kesimpulan dan Saran}

\section{Kesimpulan}

Analisis kandungan senyawa hidrokarbon, selain penentuan terhadap distribusi rantai karbon, pengamatan terhadap klasifikasi senyawa hidrokarbon juga telah dilakukan. Dari pembahasan ditarik kesimpulan a) Hasil pengamatan menunjukkan bahwa hasil komposisi bahan baku Produk Cair Sampah plastik pada proses distillasi menentukan arah kecenderungan pembentukan senyawa-senyawa hidrokarbon yang dihasilkan.b) Pemanasan yang berbeda-beda ini bertujuan untuk pemurnian distilat yang lebih dari platplat di bawahnya. Semakin ke atas, semakin tidak volatil cairannya.

\section{Saran}

Pengujian lebih lanjut perlu dilakukan untuk mengetahui hasil distilat yang murni dan dapat menghilangkan fraksi ringan sehingga memungkinkan kandungan senyawa hidrokaron menghasilkan jumlah karbon yang lebih banyak, dan bisa setara dengan bahan bakar minyak pada umumnya. 
Chemica

Volume 2, Nomor 1, Juni 2015, 21-27

ISSN: $2355-875 X$

\section{Daftar Pustaka}

[1] -,2015. Bisnis Makan dan Otomotif Dongkrak Bisnis Industri Plastik. www.kemenperin.go.id, 17 Juni

[2] Norsujianto, T., 2014. Konversi Limbah Plastik Menjadi Minyak Sebagai Bahan Bakar Energi Baru Terbarukan. JURNAL ELEMENT, Vol. I No.1. Politeknik Negeri Tanah Laut.

[3] Ermawati, R. 2011. Konversi Limbah Plastik Sebagai Sumber Energi Alternative. Jurnal Riset Industri. Vol. V, No. 3, 257-263.

[4] Zuhra, C.F., 2003. Penyulingan, Pemrosesan Dan Penggunaan Minyak Bumi, Digitized USU digital library, Medan.

[5] Heywood, J.B., 1988. Internal Combustion Engine Fundamental. McGraw Hill Publications. p.491-667.

[6] Soebagio. 2005. Kimia Analitik II. Universitas Negeri Malang, Malang

[7] Ancheyta, J., and Speight, J.G. 2007. Hydroprocessing of heavy Oils and residua. Taylor \& Francis Group, LLC. CRC Press. New York. 